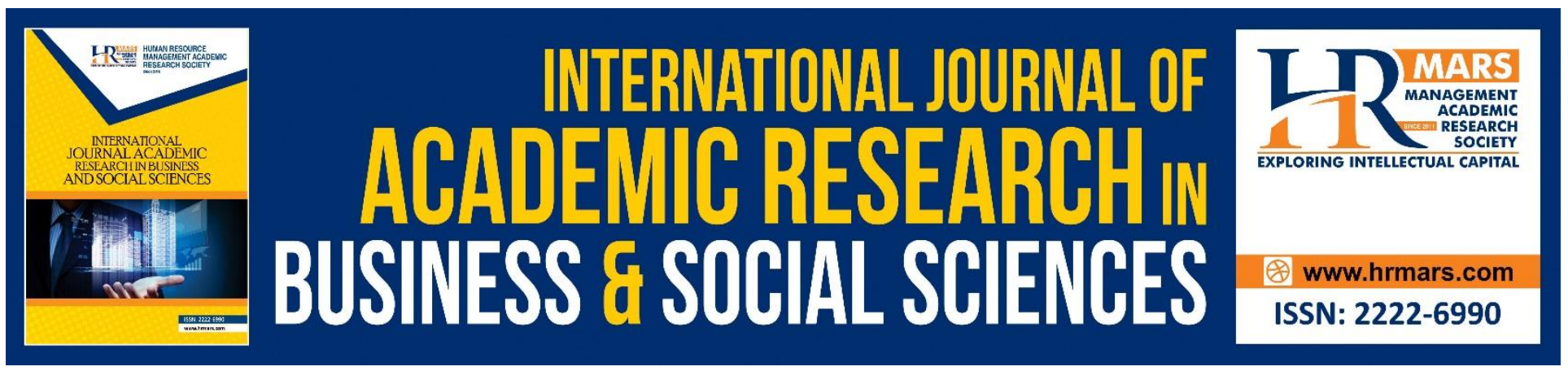

\title{
Determination of Motivational Behavior by Implementation of Theory of Planned Behavior: A Study on Teachers of Higher Education Sectors of Punjab
}

Shaista Hussain

Tasawar Javed

To Link this Article: http://dx.doi.org/10.6007/IJARBSS/v9-i3/5792

DOI: $10.6007 /$ IJARBSS/v9-i3/5792

Received: 15 Jan 2019, Revised: 15 Feb 2019, Accepted: 1 March 2019

Published Online: 24 March 2019

In-Text Citation: (Hussain \& Javed, 2019)

To Cite this Article: Hussain, S., \& Javed, T. (2019). Determination of Motivational Behavior by Implementation of Theory of Planned Behavior. A Study on Teachers of Higher Education Sectors of Punjab. International Journal Academic Research Business and Social Sciences, 9(3), 1232-1249.

Copyright: (C) 2019 The Author(s)

Published by Human Resource Management Academic Research Society (www.hrmars.com)

This article is published under the Creative Commons Attribution (CC BY 4.0) license. Anyone may reproduce, distribute, translate and create derivative works of this article (for both commercial and non-commercial purposes), subject to full attribution to the original publication and authors. The full terms of this license may be seen at: http://creativecommons.org/licences/by/4.0/legalcode

Vol. 9, No. 3, 2019, Pg. 1232 - 1249

http://hrmars.com/index.php/pages/detail/IJARBSS

JOURNAL HOMEPAGE

Full Terms \& Conditions of access and use can be found at http://hrmars.com/index.php/pages/detail/publication-ethics 


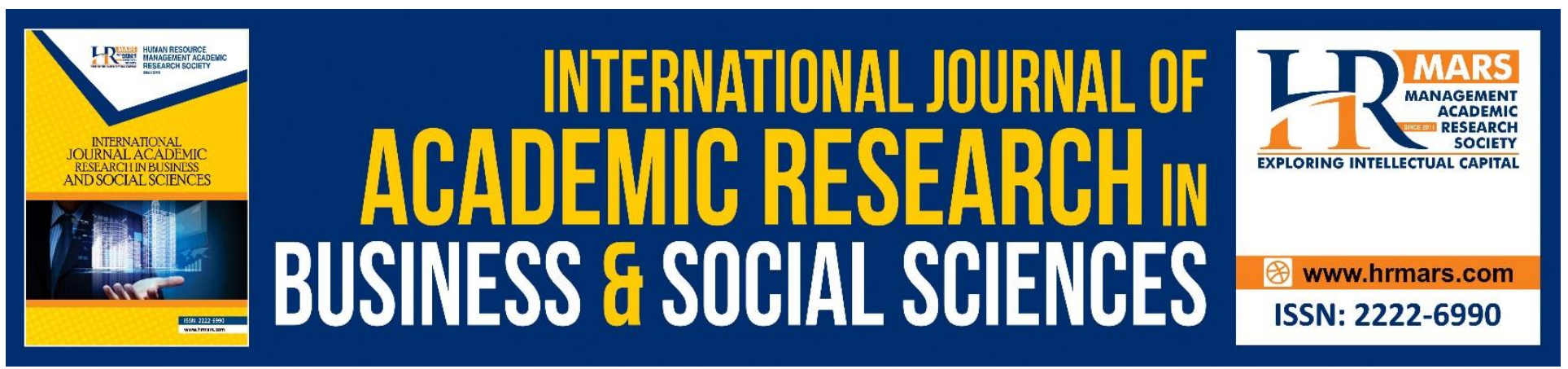

\title{
Determination of Motivational Behavior by Implementation of Theory of Planned Behavior. A Study on Teachers of Higher Education Sectors of Punjab
}

\author{
Shaista Hussain \\ Scholar, National College of Business and Economics, Bahawalpur \\ Tasawar Javed \\ Assistant Professor, DMS, IUB
}

\begin{abstract}
The study seeks systematic identification of motivational factors and investigated impact on motivational behavior of teacher's through implementation of theory of planned behavior in higher educated sector of Pakistan. Data was collected through survey by adapted questionnaire from teachers of various universities of Punjab. The analysis was conducted through smart PLS (Partial Least Square) while using SEM (Structural Equation Modeling) technique. The analysis phase of the study consists of two parts: One part contains measurement model assessment while second part throws lights on structural model assessment in which testing the hypothesis including direct and indirect hypothesis. Motivational behavior of teacher's is dependent variable, intention to stay is the mediator and extrinsic factor, attitude towards teaching, subjective norm and perceived behavioral control are independent variables. Major findings of this research study were extrinsic factors were identified as the motivational factors. Previous research mainly focused on the students motivational factors and very few considered the factors of teacher's motivation. This study tries to fulfill this gap by investigating and identifying the motivational factors and their effect on motivational behavior of teacher's.
\end{abstract}

\section{Introduction \& Background}

The education system of Pakistan consists of three main levels, primary education, secondary education and higher education institutions. There are 109 public and 74 private higher education institutes in Pakistan. The universities/ degree awarded institutes and the affiliated institutes are considered the higher education institutes of Pakistan (Halai, 2013).There are three types of 
resources in any organization that are physical, financial and human. The most important resource in them is human resource. The humans perform the important role in the development of the organization and increase the progress of the organization. Humans improve the organizations efficiency and supportive in achieving the goals of the organization (Rasheed, Aslam, \& Sarwar, 2010). Universities are the center of higher education. The teachers play the important role in the educational institutes. They teach the students, delivered the updated knowledge and enhance the students skills to compete in the challenging environment (Sarwar, Aslam, \& Rasheed, 2012).The students gain higher education in universities and learn the professional skills and new knowledge that is necessary for their future. The qualified teachers teach and train their students according to the competitive and challenging environment. The teacher's motivational behavior also impacts on students learning. So the higher education institutions must focus on teacher's motivation (Dahl \& Smimou, 2011).According to (Rasheed, Humayon, Awan, \& Ahmed, 2016) the higher education commission of Pakistan to put its maximum efforts to improve the teacher's performance. For improving teachers motivational behaviors the higher education commission reconsider the motivational factors such as salary packages, rewards, bonuses, paid leaves, medical leaves, facilities and foreign scholarship for their higher qualification. Behind this the higher education commission demands the teachers become committed to their institution, make perfection in their deficiencies and teach honestly to their students. The motivated teachers perform their tasks efficiently and effectively.

There are two types of motivation: intrinsic motivation and extrinsic motivation. The intrinsic motivation refers to motivation that comes from inside an individual. When people are internally motivated to do something it brings them pleasure (Deci and Ryan, 2000). Dornyei and Csizer (1998) explain the factors of intrinsic motivation. These factors such as: develop relation with learners, build the learners self-confidence, develop the learning process and increase learner's goal orientation. The teachers use these factors to internally motivate of their students. The extrinsic motivation comes from outside like physical rewards like money, incentives, bonuses etc (Komaki, 1982). The motivation of university teachers in Pakistan through salary is challenge for the government and it is difficult to competing with the private sector universities in compensation. The public sector universities must have to give attention to the non-monetary factors such as recognition, feedback and opportunities for career development to retain their high quality.

One of the most important and respectable profession in the world is teaching. In the society all the other professions have roots in the teaching profession. In Pakistan, the policies and plans of the government has not been focused to find out the factors that cause low motivation or de-motivation of teachers instead the government focused only on the professional development of the teachers, which include the training of teachers. Martin, Webb and Ashton (2003) explain a lot of researches are available on student's motivation. But limited researches are conducted on the teacher's motivation in the higher education institutes (Martin, 2003). This research incorporates the theory of planned behavior to addressing the most unaddressed area of higher education institutions that is teacher's motivation. This research has explained several motivational factors that are important for the university teachers. These factors increase the teachers work performance in order to increase the institutional effectiveness. 
Teachers are the pillars of any educational systems. The universities work on teacher's motivation and offering attractive salary packages, compensation, empowerment, rewards, bonuses, medical leaves and other benefits. But due to these they don't competes the private higher education institutes in salary packages, compensation and other facilities. Many skilled teachers attract to the private higher education institutions due to these facilities (Jose \& Chacko, 2017). The current research considers the theory of planned behavior to identify the motivational issues of the teachers in higher education institutions of Pakistan. Elaborate the problems which highlight the factors that create hurdles in achieving high teacher's motivation in the universities.

\section{Problem Statement}

There are different stages of education: primary education, secondary education, college or university education. Universities are the higher education sectors where teachers play an important role in ensuring high quality of education. The motivation of teachers is related with students learning and achievement. Moreover, the previous literature on teacher's motivation, the different authors explored the various motivational issues for teachers in the universities (Muhammad 2010). The majority of the teaching staff searches the other income generating activities to increase their academic salaries. The money is the main factor at every stage but money alone cannot increase the motivation of every employee. The training is the most important activity and it is mostly used in the motivational program for employees' development (Rasheed et al., 2016).

The teacher's motivation highlight that higher education commission of Pakistan is extremely focused on improving the performance of universities. For the improvement in universities, higher education commission of Pakistan has taken different steps for the teacher's learning and development. In this way they can improve the progress in higher education institutions. The initiatives of higher education commission include training for teacher's, workshops, increasing salary packages, national and international scholarship and much more. But still the teachers motivational issue is exist on the workplace. (Rasheed et al., 2010). Different researchers like Martin, Ashton and Webb (1986) and Davidson (2005) have found in their research that although sufficient research is available on student's motivation but very little effort has been made to deal with the issues of teacher's motivation. (Visser, 2012). However, teacher's motivations for teaching in higher education are rarely studied (Rasheed et al., 2016).

In the public institutions of Pakistan, the teacher's motivation by salary only is quite challenging for the government and it is difficult to compete with the private universities. They must have to give attention to the non-monetary factors such as recognition, feedback, participate in decision making, empowerment and opportunities for career development to retain and motivate their high quality teacher's.

Current research incorporate the theory of planned behavior to identify the teacher's motivational issues in the higher education institutions of Pakistan. Explain the problems which highlight the factors that create hurdles in achieving high teacher's motivation in the universities. This research helps out the authorities of universities in Pakistan to understand the teacher's motivational behavior and work on the issues and problems of teacher's motivation. 


\section{Objectives}

The objectives of the study are threefold. Which includes following; 1) To identify the various motivational issues and problems for the teachers in higher education institutions of Pakistan, 2) To find out whether the teacher's motivation has any effect on their morale to perform, 3) To identify differences in attitude, subjective norms and perceived behavioral control through implementation of theory of planned behavior.

\section{Literature Review}

Reiss (2014) the meaning of motivation is passion, curiosity and commitment and it shows the people willingness towards work. It is an intention to behave in certain way. In psychology, the forces that determine behavior, emotions and cognitive, these initiate and strengthen the behavior.

Robinson (2012) motivation strengthens the behavior, provides the way to behave and underlines the propensity for persistence. The motivation is a psychological process and it generates according to the needs. If individuals have no need then the process of motivation fails. It is the behavioral concept and it directs the human behavior towards the certain goals. The motivation is a continuous process because human needs and wants are unlimited. If persons doing well on their job then they promote their incentives. The positive motivation promotes the incentives and the negative motivation threatens the enforcement of disincentives.

\section{Attitude towards Teaching}

According to theory of planned behavior the attitude, subjective norm and perceived behavioral control are the different factors of behavioral intentions. The attitude is the personal factor between these three determinants. This is called as behavioral belief. Fishbein and Ajzen (1975) explain that attitude is the creation of an individual about the object. The individual's attitude about the object is the function of person's evaluation.

According to Ajzen \& Fishbein, (1975) the individual's attitude towards a behavior can be determined from the evaluation of behavior consequences. Moreover, attitudes can be used to predict behavior. It develops understanding about why individuals want to perform the certain behaviors and why not others.

The attitude is the person evaluation about people, things and places. The person learns and organizes the attitude through experiences. The theory of planed behavior explains the positive attitude towards the behavior. Because the intentions have an impact on behavior performs. In this the organizations observe the persons response against the people, places and things. . When sees the attitude in the theory of planned behavior it linked with efficient performance appraisal system and learning environment ( Ajzen \& Fishbein, 1980).

The attitudes are the key to improve the quality of educational institutions. The teacher's attitude towards their job has a great impact on institutional development and student's learning. If teachers have the positive attitude towards their job then performs well on their jobs. They become motivated to do some initiative on their jobs. The educational authorities observe the teachers response against the intrinsic and extrinsic factors. Then they take decision about the motivational factors of the teacher and the appreciation system and environment conditions (Alkhateeb, 2013). 
It also defines the satisfaction of teacher's on their jobs. The teachers are the nation builders and the development of a nation totally depends on the teacher's. So the teachers are the main factor in the education sector. In the absence of teacher the educational sectors cannot work properly. It is really important to find out that the teachers have the positive or negative attitude towards their job. So it's the main responsibility of the higher educational institution to improve the teacher's perceptions towards their jobs (Alkhateeb, 2013)

\section{Subjective Norm}

The persons perform those actions which decide others. According to Ajzen (2001) the two main components of subjective norms are normative beliefs and outcome evaluation. In the normative belief, the person give importance to the others belief who are important for him. The others make decision he perform the give behavior or not and he give importance to their decisions and beliefs. In the outcome evaluation, the person evaluates each belief in positive or negative way (Ajzen, 2001). According to theory of planned behavior its factors like attitude and subjective norm are explain the positive intention to perform a particular behavior. The family, friends, peer and colleagues all impact on the person intention to behavior perform. When subjective norms high then it have strong impact on intention to perform a behavior (Thomas \& Mlenga, 2016).

According to the theory of planned behavior the subjective norm is the social factor of intention and behavior. It is the social influence on behaviors and it is a function of beliefs (Ajzen \& Fishbein, 2004). In the higher educational institutes the teachers are the main components and students learning totally depends on them. Sometimes the teachers act according to others suggestion. They perform those behaviors that other approve or disapprove. The others people are friends, colleagues, family members such as parents, siblings, brother, sisters. The teachers perform some action because he/she is motivated or even under social pressure to perform or avoid performing(Ajzen, 2005).

The universities offer the salary according to the teacher's designation. They also offer compensation and benefit packages to the teaching and non-teaching faculty. They provide time to time trainings and workshops to the teaching faculty and the administrative staff. When others who are important to us give their opinions that your institute provides good salary and benefits packages. Then teacher's become motivated on their jobs and perform their duties in the effective way. Then the teachers attend the workshops and training sessions properly because according to others these are important for professional development. The subjective norm has a strong relation with intention and it can be measured with multiple item instruments (Rasheed et al., 2010)

\section{Perceived Behavioral Control}

It is the factor of intention of behavior according to the theory of planned behavior. It deals with the issues of control beliefs. It relates to our sense of self-efficacy and ability (Ajzen, 1991). It is individual belief that the behaviors outcomes are under his control or not somewhat than under the control of others that are important for them or under external factors (Ajzen \& Fishbein, 2004).

In the educational sectors the teacher's recognizes their ability and their self-efficacy. When teachers are confidential on their skills, abilities and knowledge then they deal with the unexpected events or risks confidently. They face several difficult problems on their jobs. But they always manage and try hard to solve these problems. They estimate opportunity and resources affect one's perceived 
behavioral control. They recognize the available resources and the opportunity to perform a given behavior, the greater is the perceived behavior control over the behavior (Ajzen, 1991).

The theory forecasts only those behaviors that are not straightforward. In certain situations the perceived behavioral control has minor use to predict the behaviors. For example, when individuals do not know about the given behaviors due to the new external factors and when resources or working conditions are changed. When individual have not complete control to predict the intentions or behaviors. Then they use the TRA in that situation. For behavior prediction the intention and PBC are very helpful. It proves that perceived behavioral control has direct and indirect connection with the behavior. The teachers in the universities are confident on their efforts and also have control on their behavior and certain situations. The perceived self-efficacy is "concerned with judgements how the other execute the course of action to deal with the prospective situation" (A Bandura, 1982).

Bandura, (1992) discuss the concept that is change from the existing concepts. He stated that the theory of planned behavior reflects only on external determinants; however the concept of selfefficacy focuses on internal components like cognitive perceptions of control. Armitage \& Conner (2001)explain the two concepts that perceived behavioral control is mostly used predict behaviors and intentions add the average of $6 \%$ to predict the intention in addition to attitude towards the behaviors and subjective norm.

\section{Intentions to Stay}

The intentions are the individual's decision to take different actions in different situations. This is the motivation to execute a behavior. According to the theory the intentions very important predictor of behavior (Sheeran, 2002). It identifies the individuals have not complete control on their behavior because sometimes the contradictions exist between intentions and behavior (Ajzen, 1991). The intentions used to predict the behavioral intentions describe the actual proportion of the change in future behavior (Ajzen, 2005).

The teacher's intentions to stay or leave the institution based on internal or external factors. Many factors lead the teachers intentions in higher educational institutes include fairness of treatment, training and development, responsibility, leadership, compensation/ salaries, work environment and promotional opportunities. If these factors are available on the workplace then teacher's become motivated on their jobs. Otherwise they face many problems on their jobs and their intentions develop to leave the institution. Overtime the intentions of individual change according to the situations. The repeated behaviors become the routine or habit but according to Ajzen (2005) the intentions of these behaviors still have strong predictor power. In our daily routine, our behaviors are under the volitional control, i.e. the individual easy take a decision to perform a certain behavior or not. So the teacher take a decision to perform a certain behavior on their job is totally depends on their intentions. The intentions mediate the relationship between attitude, SN and PBC. The other behaviors face higher levels of uncertainty and in this situation we have incomplete volitional control on our behavior.

The behaviors that are under the incomplete volitional control are influenced by both internal and external factors. Some individuals managed and modified their behavior according to the situation and some are not. Some factors that exist in the environment are influenced and interrupt those 
INTERNATIONAL JOURNAL OF ACADEMIC RESEARCH IN BUSINESS AND SOCIAL SCIENCES

Vol. 9, No. 3, March, 2019, E-ISSN: 222 2-6990 @ 2019 HRMARS

behaviors that we want to perform (Ajzen, 2005). When individuals have complete control on the behavior then they want to perform the behavior in according to their intentions.

\section{Extrinsic Factors}

The extrinsic motivation is the monetary rewards such as salary, compensation packages, work environment, work conditions and job security. According to Kalimullah et al., (2012) factors can affect the work nature are the contributing factors. These factors are most important for the teacher's motivation. The result is that, work is a mean to follow the other motives.

\section{Common Extrinsic Motivational Factors}

The employees want the attractive salary packages against their efforts. Money is the essential encouragement and no other incentives or motivational techniques competes it. It retains and motivates the individuals on the job. The motivated individuals do their work in the best way and show the higher performance. The attractive salary and compensation packages motivate the teachers and directly related with the employee's performance (Kalimullah et al., 2012). Rewards are the organization tool and it has a main contribution to raise the individual and group behavior. Educational institutions encourage their employee's performance by the payment, promotion and many other rewards. The institutions use the salary as a key motivator. The administration of educational institute must consider the salary structure. It shows the importance of institutions that attached to each job and pay the individual according to their performance (Rukhmani et al 2010). The leadership is doing the task in the proper way. To achieve the leadership on the workplace people should be follow you and trust on yourself. Motivation is needed to getting followers they can trust on you and work for organization. The theories point out the preference between leaders and followers one another on huge moral level and extra motivation. Motivation is such a leadership behavior. That have desire to perform beneficial task for the organization. Leadership and motivation both are explain as active management process. (Eyal \& Roth, 2011).

The work environment plays a very important role in employee motivation. The employees have the concern with the comfortable working environment that provides them extra level of motivation. The lack of pleasant working environment affects the mental and physical well-being of employees seriously. The factors such as working hours, temperature, noise, hygiene and lighting are the part of work environment(Rasheed et al., 2016). The negative performance is the result of poor working conditions. The teacher's job demands the mental and physical comfort. Moreover, when teachers realize that management does not appreciate them then they use lame excuse of poor working condition to getting views about their previous work progress. (Whittaker, 2008).

The promotional opportunities also affect the motivation of teacher's. In any institute the employees have a strong desire for promotion. It creates change in the content of job, pay, responsibility, independence and status between the others. The average employees expect only single or a couple of promotion during their whole work duration. In private sector, promotional chances are more than public sector. When employees take promotion as an achievement on their job then they looks really satisfied. When educational institutes provide better opportunities of promotion and peaceful environment according to their ability then then teachers become highly motivated and satisfied (Sarwar et al., 2012). 
INTERNATIONAL JOURNAL OF ACADEMIC RESEARCH IN BUSINESS AND SOCIAL SCIENCES

Vol. 9, No. 3, March, 2019, E-ISSN: 2222-6990 @ 2019 HRMARS

\section{Motivational Behavior of Teacher's}

According to Monday, Holmes and Flippo (2010) the motivation is a process of stimulating an individual to take decision and action in order to achieve a specific desired goal. Morgan, King and Robinson (2014) defined "motivation as a state, which individual derives behavior towards some specific goals". It plays a very important role to attain the goals of education through teaching and process of learning.

The motivation is necessary for strategic achievement and implementation of education framework. The motivation of teachers is very essential for different reasons. It is important for teacher's creativity, achievements and motivates the teachers. The motivated teachers work more effectively for institutional reforms and for flexible legislation. It is especially important at the higher educational level. The motivated teacher's is the guarantee of the achievement of reforms that are originated from the educational policies.(Mifsud, 2011).

The teachers are the most important factor to determine the nature of education that students gain. (Varlaam, Nuttal, \& Walker (1992) stated that the execution in learning is directly related to the teacher's motivation. The matter of teacher's motivation is important because it has a connection with the nature of training (Eyal \& Roth, 2011). The teacher's creativity affects the delivery of quality education. The extrinsic factors (including compensation and allowances, professional advancement, promotion and award plans) and intrinsic factors, (for example, capacity and skill, consultation, goal accomplishments, acknowledgment and great interpersonal relationship) effect on teacher motivation. (Donkoh, 2016).

(Ololube, 2006) explored the same viewpoint that the extended motivation of teachers increases the profitability of the educational institution. The training is necessary for the teacher's skill development. The training enhances the teacher's skill, abilities and knowledge. The trained teachers perform well on their jobs. The trained and satisfied teachers are more productive from the untrained and unsatisfied staff. They also impact on the student's goal accomplishment.

\section{Theoretical context of the study}

Icek Ajzen \& Fishbein, (1980) proposed theory of planned behavior. The theory of planned behavior is the extension of the theory of reasoned action. The theory of planned behavior describes intention with three main antecedents that influence on behavior namely; attitude, subject norms, and perceived behavioral control (Thomas \& Mlenga, 2016). The theory of planed behavior explains the positive attitude towards the behavior. Because the intentions have an impact on behavior performs (Ajzen et al., 1991). In the subject norms the persons give importance about others perceptions and decisions (Ajzen, 2001). The person gives importance to the social accepted norms and he neglect the reality. The person gives importance their family, friends and colleagues perceptions and decisions. The perceived behavior control explains the person perception about their skills and abilities to perform a given behavior (Liñán \& Chen, 2009). The perceived behavior control has a direct link to the control belief. The theory of planned behavior explain that when person have a confidence about their skills and abilities then he clearly make decision to perform behavior or after some to perform behavior (Ajzen et al., 1991). 
INTERNATIONAL JOURNAL OF ACADEMIC RESEARCH IN BUSINESS AND SOCIAL SCIENCES

Vol. 9, No. 3, March, 2019, E-ISSN: 2222-6990 C 2019 HRMARS

\section{Framework:}

Current study presents the following framework and variables to be examined.

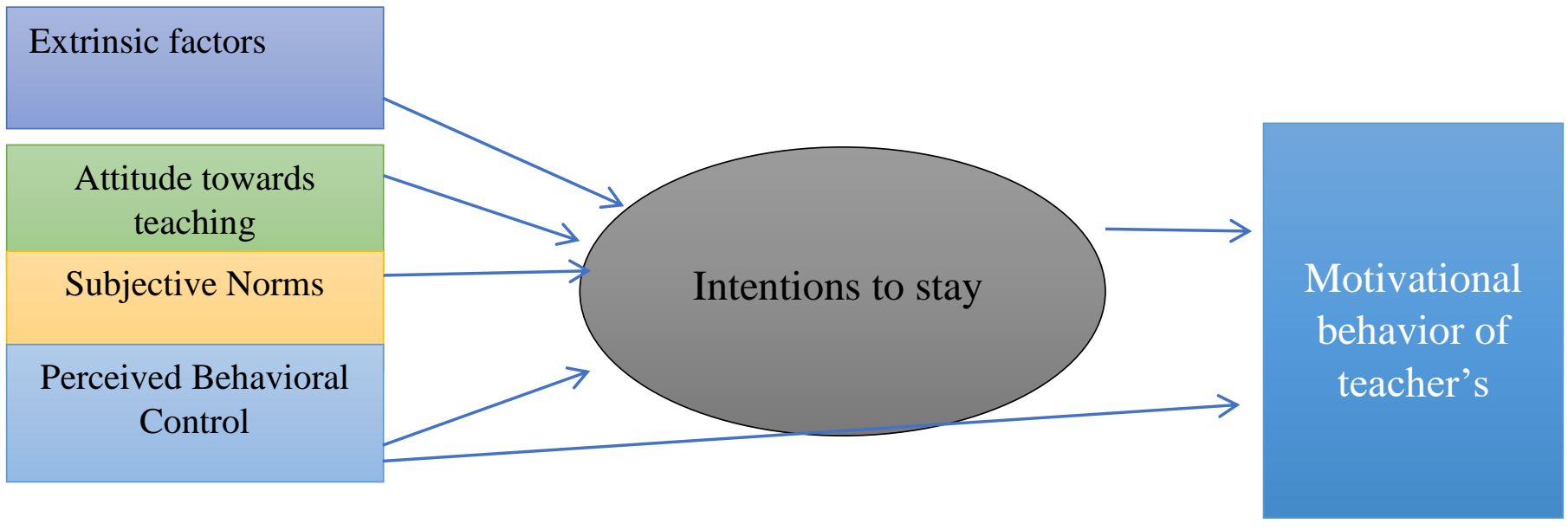

\section{Statements of Hypothesis}

$\mathrm{H} 1$ : Intentions to stay has significant impact on motivational behavior of teacher's.

$\mathrm{H}$ 2: Extrinsic factor has significant impact on intentions to stay

H3: Attitude towards teaching has significant impact on intentions to stay

$\mathrm{H} 4$ : Subjective norm has significant impact on intentions to stay

H5: Perceived behavioral control has significant impact on intention to stay.

H6: Perceived behavioral control has significant impact on motivational behavior of teacher's.

$\mathrm{H7}$ : Intentions to stay mediate the relationship between extrinsic factors and motivational behavior of teacher's.

H8: Intentions to stay mediate the relationship between attitude towards teaching and motivational behavior of teacher's.

H9: Intentions to stay mediate the relationship between subjective norms and motivational behavior of teacher's.

H10: Intentions to stay mediate the relationship between perceived behavioral control and motivational behavior of teacher's.

\section{Research Design}

Quantitative research approach is applied to examine the relationship presented in framework of the study. The quantitative research gathers the data that is absolute, such as numerical data. This data could be examined in the unbiased manner as much as possible. The quantitative research is the more structured research because it measures the quantity or amount (Kotler, 2014). This type of research uses the statistical analysis to explain and comparisons of findings. The present study adopted the correlational design because this study identifies the teacher's motivational issues through implementation of theory of planned behavior in the higher education institutions of Pakistan. The extrinsic factors, teacher's attitude, subjective norms and perceived behavioral control 
are the independent variables. The intentions to stay are the mediator and motivational behavior of teacher's is the dependent variable.

\section{Population and Sample of the Study}

The population consisted on teacher's working in higher education institutions of Pakistan. The population size was large so the target population ( owing to mine, cost and accessibility issues) of this study consisted on the staff members across the academic staff at all higher education institution belonging to Bahawalpur, Rahimyar khan, Bahawalnagar, Multan and Lodhran. The data was collected from the academic staff at the Islamia University of Bahawalpur and the sub campuses of Islamia University that are in Rahimyar khan and Bahawalnagar, Bahauddin Zakariya University and the sub campus of Bahauddin Zakariya University that are in Lodhran and Women University Bahawalpur. The researcher selects these universities for data collection because researcher has access to these universities and sub campuses of these universities.

The researcher chooses a sample of 300 from the target population by using the formula for sample size calculation given by Yamane (1967). The researcher distributed 350 questionnaires among faculty members of universities (The Islamia University of Bahawalpur, Women University and Bahauddin Zakariya University). The response was received by 203 respondents, which satisfied my sample size.

\section{Data Collection and Measurement of Variables}

The data was collected from the selected sample by using the structured questionnaire. The questionnaire was used for the collection of primary data. With the help of questionnaire the researcher collects the accurate and exactly related data (Sekaran, 2013)

For the measurement of variables the scales were adapted from the research of different scholars. The scales were modified according to this study. The references of those researches from which the questions were adapted of different variables are given below:-

\section{Measurements}

\section{Extrinsic Factors}

William (2010) develop the questionnaire to examine the motivation factors of teachers (extrinsic factors) consisting on 04 items, measured on five point Likert Scale, where 1 is considered as strongly agree, 2 represents agree, 3 as neutral, 4 as disagree and 5 represents strongly disagree.

\section{Attitude towards Teaching}

Renthlei \& Malsawmi, (2015) developed the scale based on 09 items to measure attitude towards teaching among teaching profession. The items measured on the base of 5 point Likert scale as defined previously.

\section{Subjective Norm}

Ajzen (2013) developed scale for measuring subjective norms based on 05 items. The measurement took place on base of 5 point Likert scale. 
INTERNATIONAL JOURNAL OF ACADEMIC RESEARCH IN BUSINESS AND SOCIAL SCIENCES

Vol. 9, No. 3, March, 2019, E-ISSN: 222 2-6990 ¿ 2019 HRMARS

\section{Perceived Behavioral Control}

Schwarzer \& Jerusalem, (1995) and Schiehll \& Landy, (2014) developed scale for measuring perceived behavioral control ( self-efficacy and controllability) based on 04 items. The measurement took place on base of 5 point Likert scale.

\section{Intention to Stay}

Kumar \& Govindarajo, (2017) developed scale for measuring intention to stay based on 06 items. The items measured on the base of 5 point Likert scale.

\section{Motivational behavior of teacher's}

Ozturk \& Ok, (2014) developed 05 items scale for measuring motivational behavior of teacher's at workplace. 5 point Likert scale is used as described earlier for measuring the items.

\section{Research Method}

Two step approach for reporting PLS-SEM has been taken for analysis purpose as recommended by (Henseler, Ringle, \& Sinkovics, 2009). The studies of (Henseler \& Sarstedt, 2013) and Hair, Ringle, and Sarstedt (2013) stated that goodness-of-fit (GoF) index isn't appropriate for model validation because if couldn't separate valid or invalid models. Moreover, PLS path models was conducted in the evidence of simulated study (Hair et al., 2013). Fig below shows the two-step PLS-SEM process.

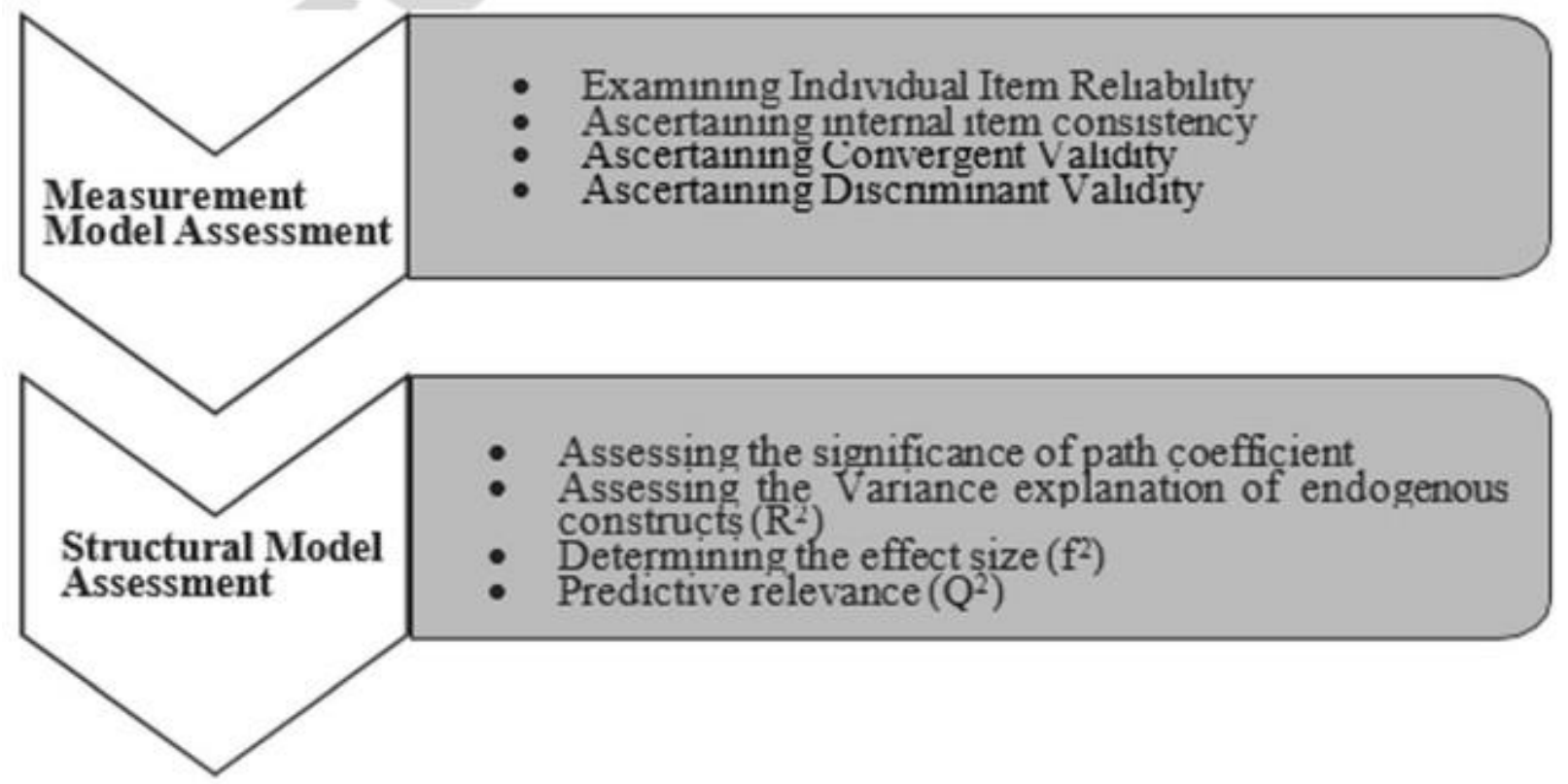

Fig: A Two-Step Process of PLS Path Model Assessment. Source: (Henseler et al., 2009). It contains the completer process of structural equation modeling (SEM) through partial least square (PLS) 
INTERNATIONAL JOURNAL OF ACADEMIC RESEARCH IN BUSINESS AND SOCIAL SCIENCES

Vol. 9, No. 3, March, 2019, E-ISSN: 222 2-6990 ¿ 2019 HRMARS

\section{Data Analysis and Results}

The analysis phase of the study consists of two parts. One part contains measurement model assessment while second phase throw lights on structural model assessment with hypothesis testing. Moreover, R-Squared $\left(R^{2}\right)$ value, effect size $\left(F^{2}\right)$, and quality is also discussed in the current phase.

\section{Measurement Model Assessment}

In the first phase factor loading, Cronbach Alpha, composite reliability and Average Variance Extracted (AVE) is discussed. Factor loading should be more than 0.5 and items below this cut off point must be deleted (Hair et al., 2010). Role for determining the value of "alpha" as " $\alpha>0.9$

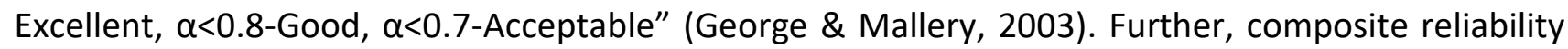
should also be more than 0.7 , and convergent validity, average variance extracted (AVE) must be more than or equal to 0.5 that achieve internal consistency.

Table 1: Factor Loading, Reliability, Convergent Validity, AVE

\begin{tabular}{|c|c|c|c|c|c|}
\hline Construct & Items/indicators & Factor Loading & Cronbach $\alpha$ & $\begin{array}{l}\text { Composite } \\
\text { Reliability }\end{array}$ & AVE \\
\hline \multirow{5}{*}{$\begin{array}{l}\text { Motivational behavior of teacher's } \\
\text { (TM) }\end{array}$} & 1. Item 1 & .762 & 0.711 & 0.811 & 0.663 \\
\hline & 2. Item 2 & .792 & & & \\
\hline & 3. Item 3 & .782 & & & \\
\hline & 4. Item 4 & .862 & & & \\
\hline & 5. Item 5 & .851 & & & \\
\hline \multirow[t]{6}{*}{ Intention to Stay (INT) } & 1. Item 1 & .766 & 0.753 & 0.831 & 0.631 \\
\hline & 2. Item 2 & .770 & & & \\
\hline & 3. Item 3 & .819 & & & \\
\hline & 4. Item 4 & .852 & & & \\
\hline & 5. Item 5 & .790 & & & \\
\hline & 6. Item 6 & .723 & & & \\
\hline \multirow[t]{4}{*}{ Extrinsic Factors (EN) } & 1. Item 1 & .790 & 0.731 & 0.798 & 0.612 \\
\hline & 2. Item 2 & .711 & & & \\
\hline & 3. Item 3 & .852 & & & \\
\hline & 4. Item 4 & .758 & & & \\
\hline \multirow[t]{9}{*}{ Attitude towards Teaching (AT) } & 1. Item 1 & .854 & 0.762 & 0.825 & 0.731 \\
\hline & 2. Item 2 & .745 & & & \\
\hline & 3. Item 3 & .812 & & & \\
\hline & 4. Item 4 & .710 & & & \\
\hline & 5. Item 5 & .723 & & & \\
\hline & 6. Item 6 & .735 & & & \\
\hline & 7. Item 7 & .760 & & & \\
\hline & 8. Item 8 & .789 & & & \\
\hline & 9. Item 9 & .775 & & & \\
\hline \multirow[t]{5}{*}{ Subjective Norms (SN) } & 1. Item 1 & .845 & 0.703 & 0.871 & 0.783 \\
\hline & 2. Item 2 & .876 & & & \\
\hline & 3. Item 3 & .756 & & & \\
\hline & 4. Item 4 & .787 & & & \\
\hline & 5. Item 5 & .725 & & & \\
\hline \multirow[t]{4}{*}{ Perceived behavioral control (PB) } & 1. Item 1 & .803 & 0.784 & 0.856 & 0.741 \\
\hline & 2. Item 2 & .701 & & & \\
\hline & 3. Item 3 & .761 & & & \\
\hline & 4. Item 4 & .823 & & & \\
\hline
\end{tabular}


INTERNATIONAL JOURNAL OF ACADEMIC RESEARCH IN BUSINESS AND SOCIAL SCIENCES

Vol. 9, No. 3, March, 2019, E-ISSN: 222 2-6990 ¿ 2019 HRMARS

\section{Discriminate Validity}

Square root of Average Variance Extracted (AVE) assisted to achieve discriminate validity, as it was examined by instructions of (Fornell \& Larcker, 1981). Table 2 shows square root of average variance extracted (AVE).

Table 2: Discriminate Validity

\begin{tabular}{llllllll}
\hline & TM & INT & IN & EN & AT & SN & PB \\
\hline TM & $\mathbf{0 . 8 1 1}$ & & & & & & \\
INT & 0.802 & $\mathbf{0 . 8 1 3}$ & & & & & \\
EN & 0.732 & 0.710 & 0.826 & $\mathbf{0 . 8 8 4}$ & & & \\
AT & 0.701 & 0.673 & 0.761 & 0.810 & $\mathbf{0 . 8 4 6}$ & & \\
SN & 0.661 & 0.652 & 0.713 & 0.752 & 0.759 & $\mathbf{0 . 8 6 1}$ & $\mathbf{0 . 8 0 3}$ \\
\hline PB & 0.614 & 0.601 & 0.691 & 0.741 & 0.698 & 0.760 & \\
\hline
\end{tabular}

\section{Structural Model Assessment}

This phase of the chapter comprises hypothesis testing, including direct and indirect hypothesis. Table 3 shows direct hypothesis testing to accept or rejection of the hypothesis, p-value 1.96 considered. Relationships with t-value less than 1.96 will be rejected and otherwise it fulfills the cutoff point of 1.96. The table 3 shows the values and status of hypothesis relations. All proposed hypothesis $\mathrm{H} 1, \mathrm{H} 2, \mathrm{H} 3, \mathrm{H} 4, \mathrm{H} 5$ are accepted, but $\mathrm{H} 6$ is rejected because T-value is 1.46 which is less than 1.96 cut off point.

Table 3: Structural Model Assessment (Results)

\begin{tabular}{lllllll}
\hline Hypothesis & Relationship & $\begin{array}{l}\text { Original } \\
\text { sample (O) }\end{array}$ & $\begin{array}{l}\text { Standard } \\
\text { Deviation } \\
\text { (STDEV) }\end{array}$ & T Statistics & P value & Decision \\
\hline H1 & INT $\rightarrow$ TM & 0.118 & 0.031 & 3.81 & 0.000 & Supported \\
H2 & EX $\rightarrow$ INT & 0.512 & 0.184 & 2.78 & 0.006 & Supported \\
H3 & TA $\rightarrow$ INT & 0.612 & 0.175 & 3.49 & 0.012 & Supported \\
H4 & SN $\rightarrow$ INT & 0.334 & 0.051 & 6.55 & 0.014 & Supported \\
H5 & PB $\rightarrow$ INT & 0.112 & 0.045 & 2.49 & 0.050 & Supported \\
H6 & PB $\rightarrow$ TM & 0.223 & 0.153 & 1.46 & 0.095 & Not- \\
& & & & & & \\
supported
\end{tabular}

\section{Structural Model Assessment Mediation Results}

Table 4 shows mediation result among variables at stated in the table. Mediation effect is significant with t-value 1.96. T-values less than 1.96 will be rejected, and $p$-value above 0.05 will be rejected as specified characteristics.

H7: hypothesis is supported with T-value 2.09 and P-value 0.031.

H8: hypothesis is supported with T-value 3.0 and P-value 0.002 .

H9: hypothesis is supported with T-value 5.200 and P-value 0.000.

H10: hypothesis rejected due to $1.28 \mathrm{~T}$-value and $0.485 \mathrm{P}$-value. 
INTERNATIONAL JOURNAL OF ACADEMIC RESEARCH IN BUSINESS AND SOCIAL SCIENCES Vol. 9, No. 3, March, 2019, E-ISSN: 222 2-6990 @ 2019 HRMARS

Table 4: Structural Model Assessment Mediation Results

\begin{tabular}{lllllll}
\hline Hypothesis & Relationship & $\boldsymbol{\beta}$-value & $\begin{array}{l}\text { Standard } \\
\text { Deviation } \\
\text { (STDEV) }\end{array}$ & T Statistics & P value & Decision \\
\hline H7 & EX $\rightarrow$ INT $\rightarrow$ TM & 0.224 & 0.107 & 2.09 & 0.031 & Supported \\
H8 & TA $\rightarrow$ INT $\rightarrow$ TM & 0.345 & 0.115 & 3.0 & 0.002 & Supported \\
H9 & SN $\rightarrow$ INT $\rightarrow$ TM & 0.125 & 0.024 & 5.200 & 0.000 & Supported \\
H10 & PB $\rightarrow$ INT $\rightarrow$ TM & 0.225 & 0.176 & 1.28 & 0.485 & $\begin{array}{l}\text { Not- } \\
\text { Supported }\end{array}$ \\
\hline
\end{tabular}

\section{$\mathbf{R}^{2}$ Value}

$\mathrm{R}^{2}$ value 0.69 , which demonstrate that all the latent exogenous variables are expected to create $69 \%$ variance in indigenous variable.

Table 5: Variance Explained $\mathbf{R}^{2}$

\begin{tabular}{ll}
\hline & Variance explained $\mathbf{R}^{2}$ \\
\hline TM & .69 \\
\hline
\end{tabular}

\section{Effect Size $F^{2}$}

Value less than 0.02 shows none effect on exogenous variable. As according to Cohen (1988), 0.02 is small, 0.15 is moderate and 0.35 is strong effect size $\left(f^{2}\right)$ as citied in (Ul-hameed, Imran, Maqbool, Ahmed, \& Azeem, 2019). As shown in table 6; Extrinsic factors shows 0.025 effect size which considered as Small strength, Attitude towards teaching shows strong relation with 0.35 effect size, Perceived behavioral control shows Moderate strength with 0.30 effect size and Subjective norms show small strength with 0.02 effect size. Intention to stay the effect size value 0.35 shows strong strength of effect size.

Table 6: Effect Size $F^{2}$

\begin{tabular}{lll}
\hline Variable & Effect size value & Strength \\
\hline EN & 0.025 & Small \\
AT & 0.35 & Strong \\
PB & 0.30 & Moderate \\
SN & 0.02 & Small \\
INT & 0.35 & Strong \\
\hline
\end{tabular}

\section{Conclusion}

The study seeks systematic identification of motivational factors and investigated impact on motivational behavior of teacher's through implementation of theory of planned behavior in higher educated sector of Pakistan. Data was collected through survey by adapted questionnaire from teachers of various universities of Punjab. The analysis was conducted through smart PLS (Partial Least Square) while using SEM (Structural Equation Modeling) technique. The analysis phase of the study consists of two parts: One part contains measurement model assessment while second part throws lights on structural model assessment in which testing the hypothesis including direct and 
indirect hypothesis. Motivational behavior of teacher's is dependent variable, intention to stay is the mediator and extrinsic factor, attitude towards teaching, subjective norm and perceived behavioral control are independent variables. Major findings of this research study were extrinsic factors were identified as the motivational factors. The extrinsic factors, attitude towards teaching, subjective norm and perceived behavioral control have a significant impact on intension to stay and significant relationship between intention to stay and motivational behavior of teacher's. The intension to stay mediate the significant relation between extrinsic factor and motivational behavior of teacher's, attitude towards teaching and motivational behavior of teacher's, subjective norm and motivational behavior of teacher's except perceived behavioral control and motivational behavior of teacher's. The compensation packages must be allocated in accordance with their duties and policies for rewards management; it must be initiated for development of the higher educational institute. The motivational behavioral change must be initiated about teacher's motivation for young or senior staff; this will help to understand the behavior of teachers. Appropriate training must be provided to the teachers to train them for better performance. The present study extends the model of theory of planned behavior. The extrinsic factors are added as the new constructs in the model. It is suggested for HEC to play its role to motivate the teachers and also understand the motivational behavior of teachers. The issues faced by the teachers regarding extrinsic factors (leadership, compensation/ salary, work environment, promotion) also generate a call for action. The issues of teacher's motivation must be resolved in order to avoid the adverse effect on the overall quality of higher education. This study is specific to the context of Pakistan, where the culture and group norms and values plays major role in determining the motivation, so the culture and group norms and values could be included to retest their effect.

\section{Recommendations}

The model may reveal some different results while studied in some other country. Data was collected from few selected universities. Moreover the sample of this study consisted of only few selected universities of Punjab province. In the future, this model can be tested to determine the effect of teacher motivation by systematically collecting the data from all over the country. This research is conducted to determine the motivational issues of teachers working in higher institutions only while future research can be conducted on other profession.

\section{References}

Ajzen, I. (2001). Nature and Operation of Attitudes. Annual Review of Psychology, 52(1), 27-58. https://doi.org/10.1146/annurev.psych.52.1.27

Ajzen, I., \& Fishbein, M. (1980). Icek Ajzen, Martin Fishbein Understanding Attitudes and Predicting Social Behavior. Understanding Attitudes and Predicting Social Behavior. Retrieved from http://0-

search.ebscohost.com.millenium.itesm. $m x / \operatorname{login} . a s p x$ ?direct=true $\& d b=c a t 00524 a \& A N=b t m . b$ 413720\&lang=es\&site=eds-live

Ajzen, I., \& Fishbein, M. (2004). The Influence of Attitudes on Behavior, (January 2005).

AJZEN, I., Netemeyer, R., \& Ryn, M. Van. (1991). The Theory of Planned Behavior. Organizational \{Behavior\} and \{Human\} \{Decision\} \{Processes\}, v, 50(JANUARY 1991), 179-211. 
INTERNATIONAL JOURNAL OF ACADEMIC RESEARCH IN BUSINESS AND SOCIAL SCIENCES

Vol. 9, No. 3, March, 2019, E-ISSN: 2222-6990 @ 2019 HRMARS

https://doi.org/10.1016/0749-5978(91)90020-T

Alkhateeb, H. M. (2013). Attitudes towards Teaching Profession of Education Students in Qatar.

Comprehensive Psychology, 2, 01.03.IT.2.9. https://doi.org/10.2466/01.03.IT.2.9

Armitage, C. J., \& Conner, M. (2001). Efficacy of the Theory of Planned Behaviour. British Journal of

Social Psychology, 40(1988), 471-499. https://doi.org/10.1348/014466601164939

Bandura, A. (1982). Self-efficacy mechanism in human agency. Amer Psych, 37(2), 122-147.

Bandura, A. (1999). Social cognitive theory: An agentic perspective. Asian Journal of Social

Psychology, 2(1), 21-41. https://doi.org/10.1111/1467-839X.00024

Controlabilidade, P. De. (2014). Perceived controllability and fairness in performance evaluation, 16(52), 484-503. https://doi.org/10.7819/rbgn.v16i52.1782

Dahl, D. W., \& Smimou, K. (2011). Does motivation matter? Managerial Finance, 37(7), 582-609.

https://doi.org/10.1108/03074351111140243

Donkoh, R. (2016). Motivation and Job Performance among Teachers in La-nkwantanang Madina

Education Directorate, (10508551), 1-96. Retrieved from http://ugspace.ug.edu.gh

Eyal, O., \& Roth, G. (2011). Principals' leadership and teachers' motivation. Journal of Educational

Administration, 49(3), 256-275. https://doi.org/10.1108/09578231111129055

George, D., \& Mallery, P. (2003). SPSS for Windows Step by Step: Answers to Selected Exercises. $A$

Simple Guide and Reference, 63. https://doi.org/9780335262588

Hair, J. F., Hult, G. T. M., Ringle, C. M., Sarstedt, \& M. (2017). A Primer on Partial Least Squares

Structural Equation Modeling (PLS-SEM), 363.

https://doi.org/10.1017/CBO9781107415324.004

Halai, N. (2013). Quality of private universities in Pakistan. International Journal of Educational

Management, 27(7), 775-786. https://doi.org/10.1108/IJEM-11-2012-0130

Henseler, J., Ringle, C. M., \& Sinkovics, R. R. (2009). The use of partial least squares path modeling in international marketing. Advances in International Marketing, 20(May 2014), 277-319.

https://doi.org/10.1108/S1474-7979(2009)0000020014

Henseler, J., \& Sarstedt, M. (2013). Goodness-of-fit indices for partial least squares path modeling.

Computational Statistics, 28(2), 565-580. https://doi.org/10.1007/s00180-012-0317-1

Holmes, M. R. (2014). Testing the Implications of an Integrated Rural Tourism Framework.

Jose, S., \& Chacko, J. (2017). International Journal of Educational Management Building a sustainable higher education sector in the UAE (2017) \&quot;Building a sustainable higher education sector in the Building a sustainable higher education sector in the UAE. International Journal of Educational Management International Journal of Educational Management International Journal of Educational Management, 31(6), 752-765.

https://doi.org/10.1108/IJEM-05-2016-0102

Kalimullah, N. A., Alam, K., \& Nour, M. (2012). New Public Management: Emergence and Principles. BUP Journal, 1(1), 1-22.

Kotler, P. (2014). Marketing Management 12, (January 1994).

Language, J. O. F., \& Studies, L. (2014). JOURNAL OF LANGUAGE AND LINGUISTIC STUDIES

Motivational behaviors of teachers in Turkish EFL classes : Perception, 10(2), 120-133.

Liñán, F., \& Chen, Y. (2009). E T \& P, 593-617.

M, D. K., \& Govindarajo, N. S. (2017). Instrument Development “Intention to Stay Instrument " (ISI 
INTERNATIONAL JOURNAL OF ACADEMIC RESEARCH IN BUSINESS AND SOCIAL SCIENCES

Vol. 9, No. 3, March, 2019, E-ISSN: 222 2-6990 @ 2019 HRMARS

), 10(12), 149-169. https://doi.org/10.5539/ass.v10n12p149

Martin, A. J. (2003). The Student Motivation Scale: Further testing of an instrument that measures school students' motivation. Australian Journal of Education, 47(1), 88-106.

https://doi.org/10.1177/000494410304700107

Mifsud, M. (2011). The Relationship of Teachers â€ $€^{\mathrm{TM}}$ and Students â€ $€^{\mathrm{TM}}$ Motivation in ELT in Malta : A Mixed Methods Study.

Ololube, N. P. (2006). Teachers Job Satisfaction and Motivation for School Effectiveness: An Assessment. Essays in Education, 18(September 2006), 1-19. Retrieved from http://www.scopus.com/inward/record.url?eid=2-s2.033846019297\&partnerID=40\&md5=f757bb52071f51f5afbadf2b54de2713

Rasheed, M. I., Aslam, H. D., \& Sarwar, S. (2010). Motivational Issues for Teachers in Higher Education : A Critical Case of IUB. Journal of Management Research, 2(2), 1-23. https://doi.org/http://dx.doi.org/10.5296/jmr.v2i2.349

Rasheed, M. I., Humayon, A. A., Awan, U., \& Ahmed, A. ud D. (2016). Factors affecting teachers' motivation. International Journal of Educational Management, 30(1), 101-114. https://doi.org/10.1108/IJEM-04-2014-0057

Renthlei, M. L., \& Malsawmi, H. (2015). Study among Secondary School Teachers in Mizoram, 1(4). Rukmani, K., Ramesh, M., \& Jayakrishnan, J. (2010). Effect of Leadership Styles on Organizational Effectiveness. European Journal of Social Science, 15(3), 365-370. Retrieved from http://0content.ebscohost.com. aupac.lib.athabascau.ca/ContentServer.asp?T=P\&P=AN\&K=56553994 \&S=R\&D=a9h\&EbscoContent=dGJyMMvI7ESeprQ4xNvgOLCmrOqep7JSsqq4TbSWxWXS\&Conte ntCustomer=dGJyMPGrrk2zr7FJuePfgeyx44Dt6fIA\%5Cnhttp://0search.ebscohost.com.aupac.lib.at

Sarwar, S., Aslam, D. H., \& Rasheed, I. M. (2012). Hindering factors of beginning teachers' high performance in higher education Pakistan. International Journal of Educational Management, 26(1), 27-38. https://doi.org/10.1108/09513541211194365

Sekaran, U. (2013). Research methods for business. Research methods for business (Vol. 65). https://doi.org/10.1017/CB09781107415324.004

Sheeran, P. (2002). Intention-Behavior Relations: A Conceptual and Empirical Review. European Review of Social Psychology, 12(1), 1-36. https://doi.org/10.1080/14792772143000003

The General Self-Efficacy Scale ( GSF ). (1995), 1995.

Thoradeniya, P., Lee, J., Tan, R., Ferreira, A., Lee, J., \& Tan, R. (2015). Sustainability reporting and the theory of planned behaviour reporting. https://doi.org/10.1108/AAAJ-08-2013-1449

Ul-hameed, W., Imran, M., Maqbool, N., Ahmed, S., \& Azeem, M. (2019). A prospective study of factors that lead to invest in mutual funds: A mediating role of investor's perception Waseem Ul-Hameed, 5, 69-80. https://doi.org/10.5267/j.ac.2018.07.002

Whittaker, C. (2008). Hotel operator motives in UK sale and leaseback/management-back transactions. International Journal of Hospitality Management, 27(4), 641-648.

https://doi.org/10.1016/j.ijhm.2007.07.031 